$\begin{array}{cccc}\text { S sciendo } & \text { International Conference KNOWLEDGE-BASED ORGANIZATION } \\ \text { Vol. XXVII } & \text { No } 1 & 2021\end{array}$

\title{
ASPECTS OF COOPERATION IN THE BALKANS BETWEEN SOE AND NKVD IN JANUARY-AUGUST 1944
}

\author{
Marian ZIDARU \\ Black Sea House Association, Constanța, Romania \\ marian.zidaru@yahoo.com
}

\begin{abstract}
A meeting was held on $14^{\text {th }}$ January 1944 to discuss the possibilities which might exist for increased collaboration between S.O.E. and N.K.V.D. in the Balkans. The following agenda was submitted: A review of S.O.E. aims in each area and an outline of their resources with the object of examining the possibilities of a concerted Balkans plan for all countries concerned. The coordination of all these plans into one directive. The possibility of discussing such a plan with the N.K.V.D. in an endeavor to enlist their cooperation and assistance in a common plan for S.O.E., O.S.S. and N.K.V.D. Our article follows the evolution of these plans during January-August 1944.
\end{abstract}

Keywords: SOE, NKVD, Balkan, O.S.S., Force 133

\section{Introduction}

Cooperation in Eastern Europe countries was difficult. No detailed study of SOE operation here can be attempted. The NKVD considered British plans regarding Hungary Poland, Czechoslovakia, Romania, and Bulgaria with deep concern. An SOE analyses report in 1944 concluded As regards Yugoslavia: The sending of a very strong Russian Mission to Tito will bring to a head the questions of future cooperation between the Russians and British in this area. This is probably the best way of getting the question settled, and SOE did not think it would be wise to take any section in Moscow to anticipate the situation which will inevitably develop out of the Russian Mission in Yugoslavia.

As regard Greece: It was impossible for the British to initiate discussions in Moscow on the question of co-operations in Greece, as the policy of E.M.G. which Great Britain were engaged in executing, was too difficult to explain.
As regards Bulgaria: This was the one country in regard to which there was some point in initiating discussions in Moscow for collaboration [1].

\section{Yugoslavia}

In Yugoslavia, there were two rival guerrilla groups within the resistance movement: a right-wing group called Chetniks led by Colonel Draza Mihajlovic and a group of communist partisans led by Josip Broz Tito. The Allies finally supported Tito's Partisan group which, proved to be more reliable and determined in their resistance against the Germans [2] Mihajlovic lived in a world that was passing, and that more British support in 1943-44 would have precipitated an even more intense and savage civil war. As for the Soviet "book" in SOE Cairo, James Klugmann, the man in question, was indeed a communist and certainly did everything he could to influence reports on the ground in favor of Tito. But many other sources, 
including the decryption of the "Ultra" system at Bletchley Park, showed that Tito's supporters were doing more to fight the Germans than Mikhailov's Chetniks, and SOE Cairo had no decision-making power over the Yugoslav issue [3]. Subversive activities have been entirely in S.O.E hands and, although the N.K.V.D have been suspected of communication with the Partisans, no proof has been forthcoming. The Soviet have expressed themselves as disinterested apart from their approval of Tito's movement and antagonism to Mihajlovic; nevertheless, they have suggested sending a mission to Mihajlovic as well as Tito and have advised against a break with Mihajlovic. With the fall of Italy, O.S.S has been admitted to participations as a minor partner and as a result of the military mission to Tito. They have accepted and have even suggested may be accepted as the first step in a Mediterranean for their operations into Yugoslavia has already been offered them Mr. Eden [4].

British deliberation on supporting either nationalist leader Mikhailovich or the Partisans in Yugoslavia, played out on the level of intelligence services as well. ProPartisans voices within SOE such as Professor Hugh Seton Watson (DH/72) eventually won the argument to switch support. For tactical reasons Soviet leaders denied any involvement in Yugoslavia. Molotov told ambassador Clark-Kerr that they would not intervene in internal conflict between Mikhailovich and the Partisans. The NKVD claimed that they have no contacts with the Partisans In facts SOE was aware this was incorrect. Although the partisans contained the best elements of the country and the majority of the educated youth, SOE officers noted that their principal objective was to establish a Yugoslav Soviet Republic. In December 1943 Molotov asked Eden to facilitate a Soviet Mission to the Partisans. The SOE told the NKVD that it was ready to offer transport and other facilities to any Soviet observation mission, reminding Soviet colleagues that Yugoslavia was under the command of the Allied commander of the Mediterranean. The Allied military mission under Brigadier Fitzroy MacLean had to be consulted regularly.

In a SOE meeting in $20^{\text {th }}$ January it was agree that the sending of a very strong Russian Mission to Tito will bring to a head the question of future co-operation between the Russians and British in this area. This was probably the best way of getting the question settled, and SOE didn't think it would be wise to take any action in Moscow to anticipate the situation which will inevitably develop out of the Russian Mission in Yugoslavia.

A report from February $25^{\text {th }} 1944$ said that no news departure Russian mission. Decision taken on high level to withdraw all liaison officers from Mihajlovic. Order issued for concentration and preparation for departure in hand.

In February $29^{\text {th }} 1944$ Col. Bailey who has been in Yugoslavia with Mihajlovic since Christmas 1942 has been evacuated. renewed signs of opposition to Mihajlovic's policy by some of his commanders have been observed. Mihajlovic appears to be trying to play off Americans against His Majesty Government.

In March $7^{\text {th }}$ brigadier Maclean has had most promising initial conversations with Russian mission who express desire for closest co-operation.

On March 281944 brigadier Armstrong endeavoring contact Mihajlovic who was still absent from his H.Q. O.S.S L. Q and Mihajlovic officer evacuated proceeded to U.S.A to present Mihajlovic case to American authorities improved weather enabled increased sorties to partisans.

In April $5^{\text {th }}$ evacuation missions held up pending final arrangements with Mihajlovic Tito pressing for permission to employ Italian soldiers of Yugoslav origin. In March 1944, SOE transported NKVD Major Konstantin Krassowski to Tito headquarters in Yugoslavia via Algiers and 
Bari, outfitting him with a wireless set a pistol and ammunition. The British found him quite unappreciative of efforts made for him on his behalf. In June, Krassowski was recalled to Moscow and Ovakimian conceded that Krassowski was the wrong type to be send.

On April $19^{\text {th }} 86$ successful sorties to partisans were recorded last week. Brigadier Maclean being evacuated with Tito's representative general Velebit for discussions A.F.H.Q Tito has made request for increased supplies of food involving very considerable air lift. Question of priorities will be discussed during visit mission to A.F.H.QA.

In a report from April 28th 1944 were reported 99 successful sorties to partisans. Withdrawal missions with Mihajlovic to coast beginning On May 10 ${ }^{\text {th }} 1944,103$ successful sorties were reported. Departure of missions from Mihajlovic area delayed until senior B.L.O has had interview with Mihajlovic. MacLean with two Tito's staff officers still London [5].

\section{Bulgaria}

Bulgaria was considered by the Allies to be of considerable strategic importance in their efforts to limit German expansion into the Middle East. The Anglo-Americans believed that the Bulgarian people did not wholeheartedly support the power of the Axis. However, economic conditions were less severe than in other parts of Europe, and Bulgarian police had experience in dealing with the disturbances. This led the British Foreign Office to argue that it would be extremely difficult for the SOE to provoke a general revolt of the people and the army against King Boris's pro-Axis regime. A better policy would have been to try to gain elements from the Bulgarian army. Initial operations to contact the main political opposition groups, such as the Left Agrarians, the Protogerovists and the Military League, failed to bear fruit. The SOE files contain a lot of information about Todoroff, a Bulgarian politician in exile and former leader of the Agrarian Party between 1923 and 1938, and about Dimitrov (Agent JOHN). The SOE found that these agents, together with other Bulgarians, tried to exploit the differences between the United States and Great Britain and between these powers and the Soviet Union over Bulgaria. The SOE files also provide details on the fate of the Mulligatawny and Claridge's mission. The death of King Boris, revitalised SOE operations in Bulgaria in the final two years of the war. The files reveal the difficulties and complexities faced in co-ordinating missions in this region [6]. NKVD did not agree to any major cooperation and subsequently should down several requests from London. SOE continued to dabble with well-intentioned schemes, for example in requesting assistance to drop supplies to Bulgarian partisans in territory the NKVD regarded as their sphere of influence.

In Bulgaria on 25 January 1944, Major Thompson was sent on a parachute landing mission to establish a link between the British HQ and the Bulgarian partisans led by Slavcho Transki; he landed near Dobro Pole, Macedonia. The commandos had a radio to keep in touch with staff in Cairo, Egypt and Bari, Italy, but it failed. On May 23, Thompson took part in the clash in the village of Batuliya between the Bulgarian Gendarmerie and the 2nd Sofia National Liberation Brigade of partisans. He was wounded by gendarmerie forces, captured and, after a parody of the trial, was executed near the village of Litakovo.

In a SOE meeting in $20^{\text {th }}$ January it was agree that Bulgaria was the one country in regard to which there is some point in initiating discussions in Moscow for collaboration.

A report from February 251944 revealed that British BLO at Yugoslav- Bulgarian border has made contact with partisan commander Sofia zone who holds out encouraging prospects partisan activities?

In February $29^{\text {th }}$ British B.L.O has submitted long report on partisan organization and targets for bombing. 
prospects were good and competent authorities interested. In a telegram from April 12.1944 London SOE told SAM that they would welcome any repercussion SAM may be able to gather in Moscow about Balkan background. London SOE would also welcome SAM appreciation of a future towards Bulgaria in event of Romanian collapse. Russian plan was to penetrating west Romania and Hungary with view to organizing sabotage etc. Russian offer of Transylvania to Romania suggests they may bethink of lines of inciting anti-German a Hungarian activities in that area if their advance is half up of Carpathians and Transylvanian Alps. Istanbul press report stated Russian about parachutists dropped Bulgaria. It was possible Russians had pinpoints there. As British had aircraft available exit was temporally out of touch, they could drop supplies to pinpoints supplied by Russians similarly when British contacts reestablished, they could give their pinpoints for them to drop store; As they were now sharing pinpoints with Russians in Yugoslavia, SOE saw no reason why same should not have been possible in Bulgaria. So, London asked SAM took up the problem with Moscow [7]. On April $19^{\text {th }}$ Leader and most of staff of mission on Western frontier now believed prisoners. Every effort being made re-establish contract with partisans. Two sorties reached area last week. On April $24^{\text {th }}$ Leader and one other member of mission now confirmed prisoners one probably killed. Rest of missions believed safe. Endeavoring infiltrate several additional missions, six successful sorties last week were reported. On May $10^{\text {th }} 3$ successful sorties were reported [8]. Mister Gore Booth's most secret letter May 23rd May to Southern Department State Department informed that further basis peace feelers had been made through the intermediary of Bulgarian Minister to Turkey who get in touch with United States representatives at Istanbul on his return from leave in Sofia.
United States Ambassador at Moscow and London have been instructed to communicate tenor of the Bulgarian proposal to his Majesty's Government and to Soviet Government, and SAM will no doubt received communications from $\mathrm{Mr}$. Winant very shortly.

London SOE learned that State Department have told to the United State Ambassador, Angora, to inform Bulgarian Minister that his proposal has been passed to British and Soviet Government, that Bulgarian Government should hold themselves ready to send an envoy to meet allied representatives preferably at Cairo, and that in the meantime Bulgarian approach will be studied from military aspect. $\mathrm{He}$ was instructed to add as his personal view that Bulgarian proposal are not sufficiently positive and that definite action on their part e.g., help in expelling German troops, will be required as evidence of a real change of heart.

Apart from informing British and Soviet Government State Department have asked United States chief of Staff for an opinion; when this has been receiving, a further communication will be addressed to the other two Governments concerned giving definite view of United States Government. Fact that it was Bulgarian Minister, Angora, who acted as intermediary has been deliberately omitted from communication which will they made to the Soviet Government as State Department have high regard of M. Balaban's personal character and if, as seems likely, present demarche comes to nothing, they didn't wish him to be prejudiced in Soviet eyes.[9] Until it is cleared up which will not be until Russians reach Bulgaria, Foreign Office were anxious to avoid political commitments to of there is no objects however to British giving material help against the Germans and London intend to give SAM sorties whenever they need them to the best of their ability. Steel says he knew this was a difficult line but hopes this explanation will 
help SAM PSE put any points which arise whenever SAM wanted to [10].

A telegram from July $7^{\text {th }}$ showed that Bulgarian Government took office after previous definitely pro-German government was forced out by Russian diplomatic pressure, this Government was fence sitting and fence compound with Russians when they approach Bulgaria. German knew this but they were too weak to take action. Russians have not broken relations with Bulgarian Government and may well be later to do a deal with them. Bulgarian government show no sign uncreased leniency towards Bulgaria Partisans or outlaw. It should be embarrassing for Britain to get too close committed to of when Russian attitude was so uncertain. Therefore, essential British agents make clear to SOE Partisans contacts that Britain were supplying then with arms to attack their common enemy as a military traction only and that SOE were not committed to of as political movement, agents should stress British desire Bulgarian Partisan activities be coordinated with Tito who of course enjoys support of Russians as well as of Britain's.

Russian attitude to of following signal sent after consultations with Steel. Soviet official attitude was unknown. SAM Moscow office has however informed NKVD that SOE have contacts with Bulgarian partisans and elicited no disapproval, Soviet press also write sympathetically but soviet government do not apparently give material because this would be inconsistent with maintenance of diplomatic relations with neutral governments. Soviets were opportunists and their attitude was in fact ambiguous [11].

The absence of an organized campaign against the Germans may be attributed to Bulgaria's status as a belligerent and the difficulties of initiating subversive action. In this respect the Russians are awkwardly placed since they are not at war with Bulgaria and cannot be expected to involve themselves officially other than from an ideological angle. They must, however, be in a very strong positions to facilitate contacts and transmit intelligence and there were some evidences that they have already been parachuting agents into Bulgaria. As a preliminary step, proper S.O.E/O. S. S. seem to take a very independent line and are most desirous of more vigorous action [12].

\section{Turkey}

In Turkey SOE tried to cooperated with NKVD because of their need to contact British agents in Balkans. Among the methods used by the SOE in developing its strategy to create communication links with its agents in Romania was the possible collaboration with the N.K.V.D. Therefore, in October 1941 after negotiations between the two governments, the SOE established contact with an NKVD agent in Istanbul, Baklanov, who acted undercover as an assistant of the commercial secretary of the Soviet Embassy in Istanbul. The meetings started in October 1941 and continued regularly until the end of the year. The SOE revealed its plans in Romania to the NKVD without revealing details and names, besides that of Maniu. The British tried to get help from the Soviets in establishing radio links but didn't manage to get it. The collaboration proved to be one-sided and the British put an end to it in February 1942, when Baklanov did not keep his promises, invoking false motives. The Soviets seemed more interested in procuring military information from Turkey than in resistance in the Balkans [13].

Turkey's neutrality has made cooperation difficult. The main incident affecting Soviet-Turkish affairs took place on the morning of February 24, 1942, when two NKVD agents, V.V. Pavlov and A.P. Kornilov, arrested in Ankara after assassination attempt on German ambassador Franz von Papen. The Turkish security service performed a detailed investigation. The investigations and trials lasted several months, and the accomplices were eventually sentenced for their part in 
the affair. The NKVD agents were ultimately convicted on June 17, 1942 [14]. After the attempt on German Ambassador Franz von Papen's life in 1942, SOENKVD contacts had been suspended for security reason. In May 1944, at British initiative, these contacts was revived with a view towards operation in Bulgaria and Romania, specifically excluding operation in Turkey itself. But the NKVD didn't name any representative, and the proposal fell. The example of Romania and Bulgaria seemed to suggest that no British intelligence work would be permitted once the Soviet troops reached former enemy territory [15]. Plans were made for countering a German invasion (blocking schemes were drawn up for the disruption of Turkish trade with Germany in strategic goods, in particular chrome [16].

In Turkey, the defection of Erich Vermehren in February 1944 raises some suspicions in Moscow as the NKVD suspected he had handled German operation against the USSR. The British denied this claim but were slow in handing over detailed reports. It lasted until July 1944 and the time when SOE history admits that the material was no longer of interest.

SOE Middle East proposed in May 1944 the resumption of SOE/NKVD Liaison at Istanbul which had been broken for security reasons after the von Papen incident in 1941. The suggestion was favorably received by NKVD and the Foreign Office approved in June 1944. In July 1944 NKVD informed Brigadier HILL that they had decided not to appoint a representative to Istanbul for the present [17].

The propaganda line that Britain was using at the time that took place in Turkey throughout the war had a longer lasting effect. The teaching of English and raising awareness of British cultural values and the British war effort, created a sympathy that was longlasting, with the effects being felt for much of the rest of the twentieth century [18].

\section{Greece}

In the remote mountain regions of Greece and Yugoslavia resistance forces gradually emerged in the aftermath of defeat. A long and appallingly brutal guerrilla war raged across much of the region for the next four years. The British faced a similar problem like in Yugoslavia in Greece, where there were also two resistance groups: The Communist-dominated National Popular Liberation Army (ELAS) and the republican Greek National Democratic Union (EDES). The two groups fought a bitter civil war until the Allies brokered a temporary ceasefire [19]. Despite the infighting, SOE agents, Army and Royal Marine Commandos, the Special Boat Service (SBS) and the Special Air Service (SAS) all fought alongside the Greek and Yugoslav resistance [20].

In a SOE meeting in $20^{\text {th }}$ January it was agree that it is impossible for British to initiate discussion in MOSCOW on the question of co-operation in GREECE, as the policy of H.M.G., which they were engaged in executing, is too difficult to explain.

A report from February $25^{\text {th }} 1944$ Conference between Zervas ELAS and EKKA leader continues. prospects satisfactory solution still no encouraging to status quo. though civil war may cease. affecting Germans will be resumed.

In February $29^{\text {th }}$ conference between guerilla organizations has been adjourned for higher level meeting between Zervas personally and E.A.M. leaders. E.L.A.S. guerillas under leadership B.L.O near mt. Olympus derailed important troop train into river Penios. Many German officers including special delegation F.N route Berlin drowned. Casualties so far confirmed 200 officers.

On March 71944 Greece adjourned conference between ELAS and Zervas reached agreement cease civil war and cooperate against Germans. Each organization will remain in its present position. And joint plans will be prepared for Epirus 
where both E.L.A.S and E.D.E.S exist. Mixed commission will supervise observation of terms minor. E.L.A.S activity against occupying forces continues following not for communication to NKVD as E.A.M delegates signed under threat of public truncation by $\mathrm{HMG}$ and as all political issues were excluded from the conference and are still unsolved excessive optimism regarding armistice is premature.

In March $24^{\text {th }}$ were reported Minor AntiGerman activity by both E.L.A.S. and Zervas continues. Archbishop and political circles Athens indicate they are prepared to co-operate with Cairo Government provided

(A) King signs secret constitutional act not to return before general election.

(B) On German evacuation Sophoulis liberal leader becomes prime minister.

King at that moment unwilling to sign constitutional act. Provisional committee in mountains sent cordial telegram to Tsouderos expressing wish to negotiate with Cairo Government and political circles Athens for formation of Government of Nation Unity.

Tsouderos has invited committee, Archbishop and political circles Athens to begin coalition negotiations either Athens or Cairo for your private information not Y.N.C.A. Tsouderos hopes if king will sign secret constitutional act coalition between Cairo Government and political circles Athens will be possible either excluding E.A.M or granting then only minor representation in new...Government.

In April $5^{\text {th }}$ s some agitation amongst armed forces in middle east in avoid of provisional committee has precipitated Governmental crisis. M Tsouderos has resigned premiers. IP advising that post should be offered to Venizelos no decision has yet been made by the king.

April $19^{\text {th }} 1944$ was reported 19 successful sorties last week. Several successful Guerilla actions by E.L.A.S forces in Macedonia and Thrace including successful wrecking of train. Blocking of shipping in
Piraeus area continues very successfully. One floating crane. One cargo ship and one tanker successfully attacked in last weeks. Prospects for settlement political issues in free Greek Government more optimistic but serious mutinies have occurred in free Greek army and naval forces.

On April $28^{\text {th }} 1944$ was reported 24 successful sorties road convoy ambushed near Edessa and train de-railed near Veria. Second train de-railed south of Katerina and bridge demolished near Domokos. Road bridge between Amphissa and Kaupactos blown. Political situation however remains unsatisfactory and internal squabbles continue. Svolos has assumed presidency of political committee in mountains with colonel Bakirdzis as vice president.

In Aegean Islands took place long developed schemes for enticement of Caiques were beginning to prove successful two enticed during week.

On May 10th was reported 20 successful sorties. A new anti-communist organization have arisen in Thessaly called E.A.S.A.D working with Germans to establish reign of terror in Volo area. Two minors clashed between E.L.A.S. and Zervas but major hostilities do far avoid. Independent Macedonian brigade of Tito's forces operating in Greek Macedonia [21].

The incident described below when a Russian mission clandestinely landed in Greece emphasizes the importance of coming to a clear understanding with Moscow in the matter of collaboration in the Mediterranean war.

On the 23rd July 1944, request was made to Air Force commanding Balkan Air Force by Russian Air Group for permission to carry out a training flight from Bari to a point just inland from the coast on the mainland of Greece opposite Corfu. The flight was authorized but had to be postponed on account of whether until the night of 25/26 July, when it took place. The permission for the flight specifically indicated that he dropped or landing operation were to be undertaken. 
Subsequently it transpired that this permission was abused in the aircraft carried a Russian colonel and up to nine other officers (number uncorked) comprising members of the Soviet mission to Tito and including Tito men, who were dropped in Greece at one of SOE landing grounds without prior knowledge of British in Cairo or Allied Mission in Cairo or Allied Mission in Greece. ALOS in Greece report arrival of this Mission at ELAS GHQ.

Colonel Sokolov Commanding the Russian Air Group, admits that after the aircraft took was diverted to a point in Greece by $w / t$ and that officer were landed in Greece. According to Sokolov, the orders for flight were received from colonel Melnikov who was acting head of the Russian Mission to Tito. Colonel Sokolov's explanation for not reporting the intention was that he has not considered the matter of sufficient importance to interest SOE.

ALOS have been instructed to maintain strictly correct but noncommittal attitude. Colonel Hammond of Allied Mission and colonel West of OSS/SO in Greece, have been ordered to proceed ELAS /HQ to report full facts.

This incident was yet another of a series of incidents with the Russians in this theatre, and amounts to a clear breach of their agreements with SOE regarding their operation of Russian aircraft in this theatre [22].

Control of subversive action has again been vested in S.O.E but O.S.S has been admitted to partnership official interest by an announcement British and American plan to back Tsouderos' pronouncement. Apart from that, the Soviet pretend to a lack of interest in Greece owing, as they say, to scanty information.

The last Soviet move may also be viewed as an acceptance of unified control and desire to cooperate. Mr. Novikov, the new Soviet Minister in Cairo, is to be kept informed henceforth of Greek developments which may arouse more interest in Moscow in Greek affairs [23].

At the end of August 1944, the Red Army had advanced into the Balkan Peninsula. The German Army in Greece and Yugoslavia retreated into Hungary and Austria.

Allied troops landed in Greece in October, but they saw little fighting as the Germans were in full retreat. The resistance had already liberated most of the country. Tito's Partisans had done the same in Yugoslavia and entered Belgrade several hours before Soviet forces arrived [24].

The Greek resistance started civil war. The British Army intervened on the side of the EDES-dominated government.

Soviet Union accepted that Greece belonged in the 'British sphere of influence' as defined in the agreement between Yosef Stalin and Winston Churchill at Moscow in October 1944 [25].

\section{Conclusions}

During January-August 1944, there were several proposals to extend the collaboration between SOE and NKVD. Between the two services, there was cooperation through the exchange of information through the two British missions to Moscow (SAM mission led by General Hill) and London (led by Colonel Chichaev). SOE also provided technical assistance to the NKVD to carry out missions in Yugoslavia. However, the NKVD looked at many of the SOE operations with suspicions it is a fact that the cooperation between the two services could not be extended.

\section{References List}

[1] PRO Kew Gardens, HS 154

[2] Uncommon Courage https://www.veterans.gc.ca/eng/remembrance/history/secondworld-war/uncommon-courage 
[3] David Stafford Was Churchill 'Hoodwinked' Over Tito? https://winstonchurchill.org/resources/in-the-media/churchill-in-the-news/waschurchill-hoodwinked-over-tito/

[4] PRO Kew Gardens, HS 154, Telegram from 20th January 1944 no AD1103

[5] Ibidem, Various Cipher Telegram to Moscow about Yugoslavia from 20h January.1944 25.2.44, 29.2.44, 7.3.44, 28.3.44, 28th 1944, 10. 5. 44

[6] SPECIAL OPERATIONS EXECUTIVE, 1940-1946:SUBVERSION AND SABOTAGE DURING WORLD WAR II Series Two: SOE Operations in the Balkans http://www.ampltd.co.uk/digital_guides/special_operations_executive_series_2_parts_1 and_2/Publishers-Note-Part-2.aspx

[7] PRO Kew Gardens, Cipher telegram to Moscow 12.4.44 fila 201

[8] Ibidem, Various Cipher Telegram to Moscow about Yugoslavia from 20h January.1944 25.2.44, 29.2.44, 7.3.44, 28.3.44, 28th 1944, 10. 5. 44.

[9] From Washington to Foreign Office Sir RI Campbell no 4063 26th July 1944 Important Top-secret fila 106

[10] Ibidem,646 Cipher Tel. from Force 133 Desp 0238 31.7.1944fila 105

[11] Ibidem, Cipher Tel. from Force 133 Desp 31.7.44 To London DANSEC 0976 from Force 133 fila 104

[12] Ibidem, Telegram from 20th January 1944 no AD1103

[13] Ibidem, "History SOE Romania", HS 7/186, fol.12.

[14] Russophobe neutrality: Turkish diplomacy, 1936-1945 pp164-168

[15] Donal O'Sullivan, Dealing with the Devil: Anglo-Soviet Intelligence Cooperation in the Second World War, pp 242-248. Peter Lang Inc., International Academic Publishers; First printing edition (March 9, 2010) 337 pages

[16] https://discovery.nationalarchives.gov.uk/details/r/C9270

[17] Ibidem, PRO Kew Gardens, HS154

[18] Edward Corse, Keeping the Pot Boiling: British Propaganda in Neutral Turkey during the Second World War, https://blogs.kent.ac.uk/munitions-of-the$\operatorname{mind} / 2018 / 12 / 04 /$ keeping-the-pot-boiling-british-propaganda-in-neutral-turkey-duringthe-second-world-war/

[19] War in the Balkans, 1941-45

[20] PRO Kew Gardens, D/HT fila 202 Cipher tell from Cairo DESP 0825 7.4.44 DHT DP 3044 LONDON RPT MOSCOW

[21] Ibidem, Various Cipher Telegram to Moscow about Greece from 20h January.1944 25.2.44, 29.2.44, 7.3.44, 28.3.44, 28th 1944, 10. 5. 44.

[22] Ibidem, Greece. Emergency from: Freedom to MSSC for British chiefs of staff RPDT Britmen for US Joint chiefs of Staff Balkan Air Force Medco's 142 3rd August 1944 PX 78848 Signed: Wilson FNCOS. f100

[23] Ibidem, Telegram from 20th January 1944 no AD1103

[24] War in the Balkans, 1941-45 https://www.nam.ac.uk/explore/war-Balkans

[25] https://www.nam.ac.uk/explore/war-Balkans 